\title{
Postnesting migratory behavior of loggerhead sea turtles Caretta caretta from three Florida rookeries
}

\author{
Allen M. Foley ${ }^{1, *}$, Barbara A. Schroeder ${ }^{2}$, Robert Hardy ${ }^{3}$, Sandra L. MacPherson ${ }^{4}$, \\ Mark Nicholas ${ }^{5}$, Michael S. Coyne ${ }^{6}$ \\ ${ }^{1}$ Florida Fish and Wildlife Conservation Commission, Fish and Wildlife Research Institute, Jacksonville Field Laboratory, \\ Jacksonville, Florida 32218, USA \\ ${ }^{2}$ National Marine Fisheries Service, Office of Protected Resources, Silver Spring, Maryland 20910, USA \\ ${ }^{3}$ Florida Fish and Wildlife Conservation Commission, Fish and Wildlife Research Institute, St. Petersburg, Florida 33701, USA \\ ${ }^{4}$ US Fish and Wildlife Service, Jacksonville, Florida 32256, USA \\ ${ }^{5}$ National Park Service, Gulf Islands National Seashore, Gulf Breeze, Florida 32563, USA \\ ${ }^{6} 1$ Southampton Place, Durham, North Carolina 27705, USA
}

\begin{abstract}
We used satellite telemetry to study postnesting migrations of 42 loggerhead sea turtles Caretta caretta from 3 Florida rookeries. Postnesting migrations ended in neritic $(<200 \mathrm{~m})$ waters of Florida, Alabama, Texas (USA), and of Mexico and the Bahamas. Most postnesting migrations were restricted to the continental shelf and were relatively direct. Migrations through oceanic areas ( $>200 \mathrm{~m}$ ) tended to be less direct, largely due to apparent influences of the Florida Current in the Atlantic and to looping travel paths (often along edges of mesoscale eddies of the Loop Current) in the Gulf of Mexico. The largest loggerheads tended to migrate to foraging grounds that were farthest from the nesting beach. Turtles spent more time near the surface $(<3 \mathrm{~m})$ when migrating than they did during residency at foraging sites, and were likely swimming just below the surface. The substantial amount of time spent near the bottom in neritic areas and the looping travel paths in oceanic areas indicate that migrating loggerheads may have been foraging. We identified 4 migratory corridors. Two were on the continental shelf of the Florida Panhandle, 1 was along the northern coast of Cuba, and 1 was along the southeastern coast of Florida. Migrating loggerheads may be uniquely vulnerable to mortality factors because of where they travel and how they behave, particularly if they are concentrated in narrow (perhaps $<10 \mathrm{~km}$ wide) migratory corridors. Characterizing the behavior and identifying the travel paths of loggerheads during postnesting migrations are necessary steps for implementing successful recovery efforts.
\end{abstract}

KEY WORDS: Caretta caretta $\cdot$ Sea turtle $\cdot$ Postnesting migration $\cdot$ Satellite tracking $\cdot$ Telemetry Migratory corridor

\section{INTRODUCTION}

Loggerhead sea turtles Caretta caretta are highly mobile marine reptiles. From the moment they enter the surf as hatchlings to their return as adults to nesting beaches, loggerheads lead a life punctuated by long-distance movements that often cross national boundaries (Salmon \& Wyneken 1987, Witherington 1995, Bolten 2003, Morreale \& Standora 2005, Mc-

${ }^{*}$ Email: allen.foley@myfwc.com
Clellan \& Read 2007, Mansfield et al. 2009). These wide-ranging movements, including ontogenetic migrations, are characteristic of marine turtles, and they result in exposure to a host of natural and anthropogenic threats, and differing management regimes to address those threats (Witherington 2003, Bräutigam \& Eckert 2006). Knowledge of key habitats is critical for identifying spatial and temporal overlap with anthropogenic threats and for develop-

(C) The authors 2013. Open Access under Creative Commons by Attribution Licence. Use, distribution and reproduction are unrestricted. Authors and original publication must be credited. 
ing and implementing effective management actions for threat reduction (Troëng et al. 2004, Coll et al. 2012). It is especially vital to identify and characterize areas used by adult loggerheads, whose survival rate has a particularly strong effect on population recovery (Crouse et al. 1987, Heppell 1998).

Adult loggerheads make periodic migrations between foraging areas and breeding or nesting areas (reproductive migrations; Schroeder et al. 2003) in addition to any seasonal movements related to foraging or overwintering strategies (Hawkes et al. 2007). Information on the reproductive migrations of loggerheads was initially obtained from opportunistic recaptures of adult females previously tagged with flipper tags on nesting beaches (Meylan et al. 1983, Limpus et al. 1992). These studies provided insights into the movements of adult loggerheads but could not provide details on the exact timing of migrations, pathways, or behavior (e.g. swim speed, swim depth) during travel. Satellite telemetry provides the tools necessary to more specifically discern these behaviors (Godley et al. 2008).

The loggerhead nesting assemblage in the southeastern United States is one of the 2 largest in the world (Ehrhart et al. 2003) and is of paramount importance to the recovery of the species (National Marine Fisheries Service \& US Fish and Wildlife Service 2008). These loggerheads are part of the Northwest Atlantic Ocean Distinct Population Segment (NAO DPS) recently recognized and listed as threatened under the US Endangered Species Act (Department of the Interior \& Department of Commerce 2011). Approximately $90 \%$ of the nesting of this DPS occurs in Florida (Ehrhart et al. 2003).

The recovery objectives for the NAO DPS involve minimizing mortality from anthropogenic sources, including those that may occur along migratory pathways, managing a sufficient amount of habitat to ensure survival, and implementing effective regulatory and non-regulatory actions that provide longterm protection to ensure survival and recovery (National Marine Fisheries Service \& US Fish and Wildlife Service 2008). Achieving these objectives requires gaining a comprehensive knowledge of foraging, breeding, and nesting areas, as well as the pathways used to travel among these habitats.

We used satellite telemetry to elucidate postnesting migratory pathways and behavior of NAO DPS loggerheads from 3 Florida rookeries (based on genetic distinctions determined by Shamblin et al. 2011). These included 1 rookery from each coast of Peninsular Florida (the central eastern and central western rookeries), and the single rookery in the
Florida Panhandle (the northwestern rookery). The foraging areas and most of the behaviors of these turtles while at foraging sites will be described in a future paper. Here, we characterize and compare the postnesting migrations of loggerheads from these 3 nesting rookeries and evaluate the data with a particular interest in revealing any behaviors that might make these loggerheads more vulnerable to anthropogenic threats.

\section{MATERIALS AND METHODS}

Nighttime nesting beach surveys were conducted at 3 Florida rookeries (central eastern, central western, and northwestern, as delineated by Shamblin et al. 2011) to locate nesting loggerheads. These surveys were conducted primarily during the latter half of the nesting season (July and August) to find turtles on their last or next-to-last nest of the year (i.e. just prior to the postnesting period). Due to relatively low nesting densities on the beaches in the northwestern rookery, we conducted the surveys there earlier in the nesting season when larger numbers of turtles were nesting (late June and July).

Turtles were intercepted after nesting and confined in a portable wooden box with an open top and $8 \mathrm{~cm}$ holes along the sides for ventilation. We measured the straight length of each turtle's carapace (from the nuchal notch to the posterior marginal tip) to the nearest $0.1 \mathrm{~cm}$ with calipers, and then affixed a platform terminal transmitter (PTT) according to the methodology of Balazs et al. (1996).

The PTT was either a ST-14 (A-2400, $16.5 \times 9.8 \times$ $3.0 \mathrm{~cm}, 750 \mathrm{~g})$ from Telonics or a SDR-T16 $(13.5 \times 4.5$ $\times 3.7 \mathrm{~cm}, 330 \mathrm{~g}$ ) from Wildlife Computers. Duty cycles for all the ST-14s were synchronized and set to $24 \mathrm{~h}$ on and $12 \mathrm{~h}$ off. Of the $10 \mathrm{SDR}-\mathrm{T} 16 \mathrm{~s}, 4$ had duty cycles of $24 \mathrm{~h}$ on and $12 \mathrm{~h}$ off (all synchronized), and 6 had duty cycles of $12 \mathrm{~h}$ on and $12 \mathrm{~h}$ off (all synchronized). The latter duty cycles were used later in the study in an effort to increase battery life. All PTTs were equipped with a saltwater switch to transmit only when the unit was above water. SDR-T16s were equipped with a pressure sensor that recorded depth every $10 \mathrm{~s}$. The diving parameter reported here was time at depth, which was the percentage of time spent within predefined depth bins. Depth-bin limits were set at 1,3 , and $5 \mathrm{~m}$, then at $5 \mathrm{~m}$ intervals to 35 , then at 50,60 , and $75 \mathrm{~m}$, followed by $25 \mathrm{~m}$ intervals to $150 \mathrm{~m}$, and finally at $>150 \mathrm{~m}$.

Geographic positions of the tracked animals were calculated by Service Argos (see Witt et al. 2010 for a 
review of this process and the error associated with the calculated positions). The Argos data were downloaded and managed using the Satellite Tracking and Analysis Tool (Coyne \& Godley 2005) and filtered using the Douglas Argos Filter Algorithm (DAF) written for PC SAS (Douglas et al. 2012). Postnesting migratory routes were reconstructed using the DAF distance-angle-rate output, which produced a subset of Argos data that passed tests for plausibility using a filter based on a minimum distance between consecutive positions $(5 \mathrm{~km})$, travel rate $\left(4 \mathrm{~km} \mathrm{~h}^{-1}\right)$, and turn angles (rate coefficient $=25$ ). The filtered positions were then reduced to the best position per day by qualitatively ranking them as described by Douglas et al. (2012). We used the location where the nesting turtle was outfitted with the PTT (or subsequently believed to nest) as the starting point of the postnesting migration and the location where residence at a presumed foraging ground began as the ending point of the postnesting migration. Residency was identified by a reduction in travel rate to less than $20 \mathrm{~km} \mathrm{~d}^{-1}$, a cessation of net movement away from the nesting beach, and an end to primarily unidirectional orientation.

We quantified the directness of the postnesting migration using a variation of the straightness index (Batschelet 1981), which is the ratio between the straight-line distance of a travel path from starting point to ending point and the length of the actual travel path. The Florida peninsula made it impossible for some of the loggerheads to migrate directly from their nesting beach to their foraging ground. We accounted for this by modifying the straightness index to use the shortest path between the starting point and the ending point of the postnesting migration that avoided land instead of a simple straightline distance between the 2 points. We called this the 'migratory directness'. A migratory route that was the shortest possible distance by water from starting point to ending point had a directness value of 1 . The more the migratory route deviated from the shortest possible path, the smaller the directness value became. Shortest possible paths were calculated using either the great-circle method across open water or, when a straight path would cross land, the shortest possible path that avoided land. The latter was derived by performing a least-cost path analysis in which land acted as a barrier and cost accumulated with path distance (ArcGIS 9.3, Environmental Systems Research Institute).

We obtained bathymetric data at Argos positions using 2 regional datasets. The 3-arc-second-resolution US Coastal Relief Model (CRM, NOAA National
Geophysical Data Center 2009) was used for animals with movements entirely within the US coastal zone. We obtained bathymetry values from the global (1arc-minute resolution) ETOPO1 dataset (Amante \& Eakins 2009) for animals tracked beyond the extent of the CRM. The bathymetry datasets also served to identify the land-water interface for least-cost path estimations. We examined ocean surface currents using satellite altimetry data. The altimeter products were produced by Ssalto/Duacs and distributed by Aviso, with support from Cnes (www.aviso.oceanobs. com/duacs/). We extracted data describing mesoscale eddies of the Loop Current within our study region from the database maintained by Oregon State University (Chelton et al. 2011). The incorporation of these ocean circulation products was facilitated by the Marine Geospatial Ecology Tools for ArcGIS (Roberts et al. 2010).

Most of the statistical analyses ( $t$-tests, paired $t$ tests, 1-way ANOVAs, and Pearson Product Moment Correlation analyses) were performed with the software SigmaStat for Windows version 3.10. Parametric tests were used only when data first passed the Kolmogorov-Smirnov test for normality. The Watson's 2-sample test for homogeneity was conducted in $\mathrm{R}$ using the circular package (Agostinelli \& Lund 2011, R Core Team 2012). We used an alpha level of 0.05 for all statistical tests.

\section{RESULTS}

We deployed PTTs on 42 nesting loggerheads at 3 Florida rookeries during 1998 to 2001 (Fig. 1). The mean straight carapace length (SCL) of the turtles was $91.1 \mathrm{~cm}$ (standard error of the mean [SEM] = 0.68 , range $=83.3$ to 102.6 ). There was no difference in the mean sizes of turtles from the 3 nesting rookeries (1-way ANOVA, $F=0.85, \mathrm{df}=2, \mathrm{p}=0.44$ ). Thirty-four of the turtles began moving continuously away from the nesting beach within $24 \mathrm{~h}$ of being outfitted with a PTT. We received high-quality positions (LC3s, see Collecte Localisation Satellites 2008) from 2 of the remaining 8 loggerheads (1 from the northwestern rookery and 1 from the central eastern rookery) that placed them on the nesting beach again (during the night) at 23 and $16 \mathrm{~d}$ (respectively) after PTT deployment. These turtles began moving continuously away from the nesting beach immediately afterwards, and we considered this as the beginning of their postnesting migration. The other 6 turtles remained in the vicinity of the nesting beach for 12 to $18 \mathrm{~d}$ before departing. However, we did not receive 


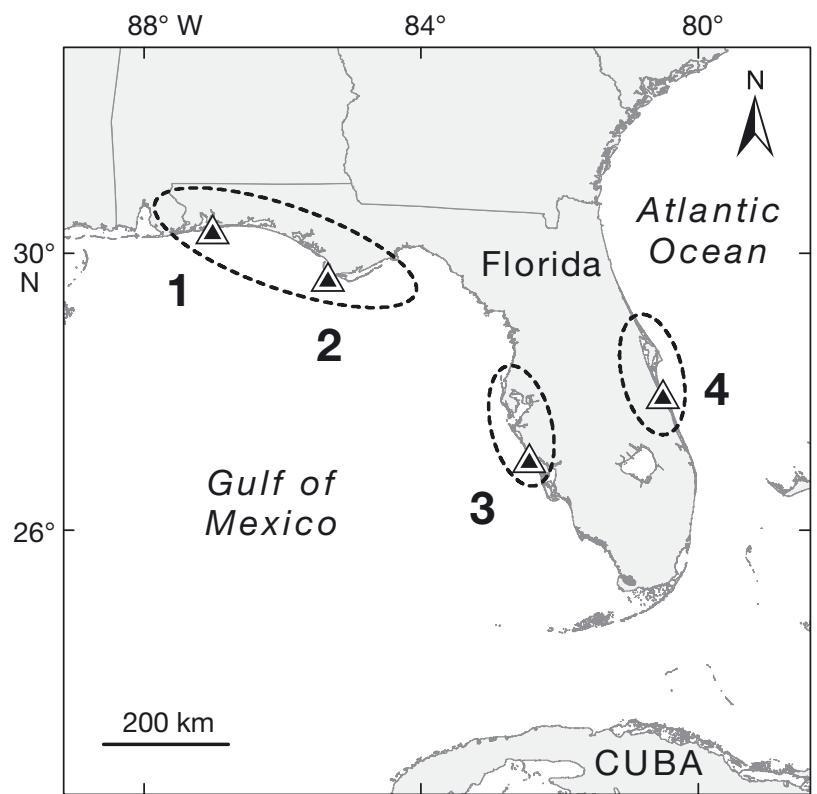

Fig. 1. Caretta caretta. Location of beaches $(\Delta)$ in Florida where nesting loggerheads were intercepted and outfitted with a platform terminal transmitter during 1998 to 2001. Four were intercepted in area 1 (Perdido Key and Santa Rosa Island, Escambia County), 10 in area 2 (Cape San Blas and St. Joseph Peninsula, Gulf County), 13 in area 3 (Manasota Key, Sarasota County), and 15 in area 4 (Archie Carr National Wildlife Refuge, near Melbourne, Brevard County). Areas 1 and 2 were within the northwestern rookery; area 3 was within the central western rookery; and area 4 was within the central eastern rookery (rookeries indicated by the dashed ovals as delineated by Shamblin et al. 2011)

any high-quality locations (LC2s or 3s, see Collecte Localisation Satellites 2008) that indicated these turtles nested again. We assumed that the postnesting migrations for these turtles began after we outfitted them with a PTT. Five of these turtles were from the northwestern rookery and 1 was from the central western rookery.

Forty of the turtles completed their postnesting migrations while we were still tracking their movements (Fig. 2). These turtles were subsequently

Fig. 2. Caretta caretta. Postnesting migratory paths of 42 loggerheads that were outfitted with a platform terminal transmitter while nesting in Florida during 1998 to 2001. (₫) Locations of the nesting beaches (see Fig. 1). (O) Ending points of migrations (residency at foraging sites). $(\diamond)$ Last known position of 2 loggerheads before they displayed behavior indicative of residency at a foraging site. Loggerheads from the (A) northwestern rookery $(\mathrm{N}=14)$, (B) central western rookery $(\mathrm{N}=13)$, and $(\mathrm{C})$ eastern rookery $(\mathrm{N}=15)$. The dashed line represents the $200 \mathrm{~m}$ bathymetric contour
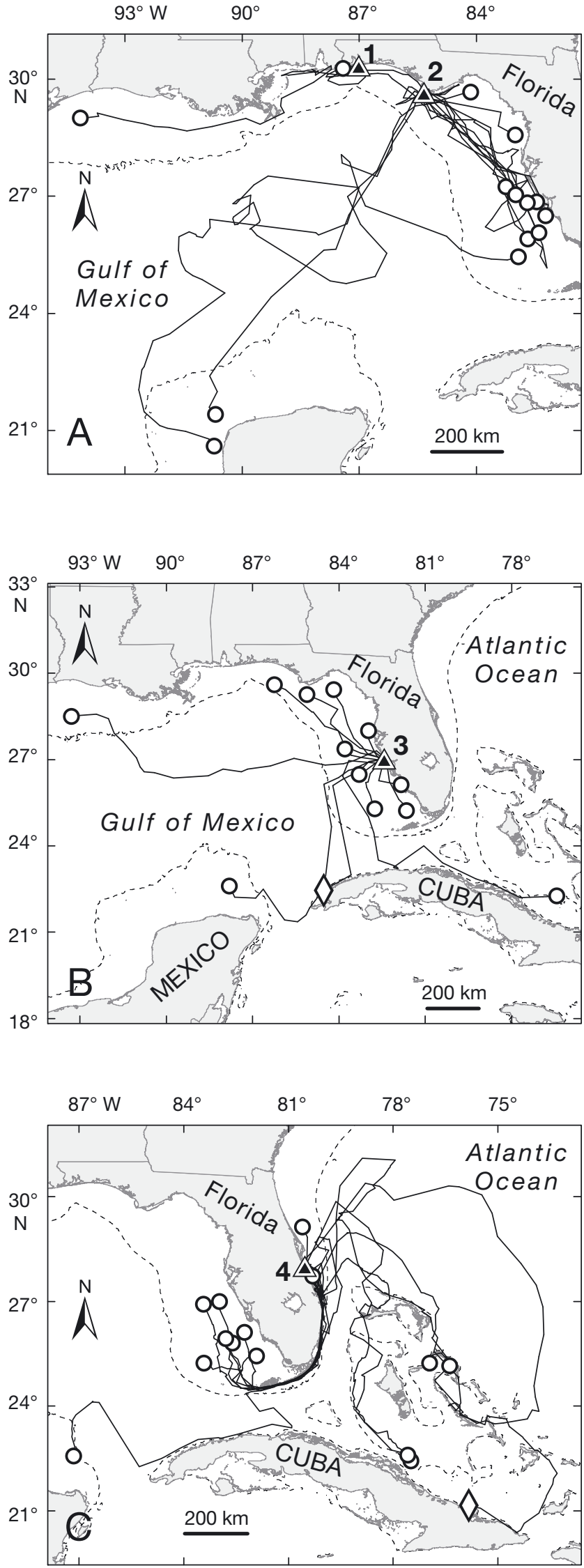
tracked during residency at foraging sites (beginning at the ending point of their postnesting migrations) for a mean period of almost $1 \mathrm{yr}(352 \mathrm{~d})$. We will report elsewhere the data associated with their residency at foraging sites (manuscript in preparation). Communication with the PTT of 2 turtles (1 from the central western rookery and 1 from the central eastern rookery) ceased while the turtles were still apparently migrating. Both were last known to be travelling along the northern coast of Cuba (see $\diamond$ in Fig. 2B,C). There was no difference in the characteristics of the postnesting migrations by rookery (Table 1). Larger loggerheads tended to travel farther during their postnesting migrations and to take less direct paths than smaller loggerheads (Table 2). As larger loggerheads did not tend to travel faster than smaller loggerheads, they thus took longer to complete their postnesting migrations (Table 2). We identified 4 migratory corridors. One was along the northern coast of Cuba (Fig. 2B,C), 2 were offshore of the eastern portion of the Florida Panhandle (Fig. 3A), and 1 was along the southeastern coast of Florida (Fig. 3B). We were able to track 1 turtle until her return to the nesting beach $2 \mathrm{yr}$ later. The migration to the nesting beach followed much the same route as her previous postnesting migration (Fig. 4).
Migratory paths that were restricted to the continental shelf (depth of $<200 \mathrm{~m}, \mathrm{~N}=29$ ) were significantly more direct (mean directness value of 0.83 , $\mathrm{SEM}=0.02$, range $=0.56$ to 1.0 ) than those that traversed oceanic waters $(\mathrm{N}=11$, mean directness value of $0.53, \mathrm{SEM}=0.05$, range $=0.28$ to 0.87$)(t$-test, $t=$ $6.33, \mathrm{df}=38, \mathrm{p}<0.001)$. The travel rates of the latter 11 loggerheads when in neritic areas (mean = $1.3 \mathrm{~km} \mathrm{~h}^{-1}, \mathrm{SEM}=0.09$, range $=0.8$ to 1.7 ) were also slower than when they were in oceanic areas (mean $=2.2 \mathrm{~km} \mathrm{~h}^{-1}, \mathrm{SEM}=0.12$, range $=1.4$ to 2.7 ; paired $t$ test, $t=6.85, \mathrm{df}=10, \mathrm{p}<0.001$ ). Five of the loggerheads from the central eastern rookery crossed the northward flowing Florida Current. While in this current, these turtles moved north-northeast for 100 to $400 \mathrm{~km}$ (Fig. 5). However, after leaving the current, all 5 turtles headed south-southeast for the rest of their postnesting migrations (Table 3, Figs. 2C \& 5). Two of the loggerheads that traveled across the oceanic waters of the Gulf of Mexico (GOM) made large-scale loops (Fig. 2A). The association of one of these looping travel paths with the edges of mesoscale eddies of the Loop Current is shown in Fig. 6.

Dive-depth data were collected for 5 loggerheads from the northwestern rookery and for 5 loggerheads from the central western rookery. The postnesting

Table 1. Caretta caretta. Characteristics of the postnesting migrations of 40 loggerheads from Florida by rookery (see Fig. 1). The mean value for each group is given with the SEM and range in parentheses. The migratory directness is the length of the shortest possible migratory path divided by the length of the actual migratory path. Results of a 1-way ANOVA comparing the means of each column are given in the last row. The means in each column are not different $(p>0.05)$

\begin{tabular}{|cccccc|}
\hline Florida rookery & $\begin{array}{c}\text { Length of most direct } \\
\text { migratory path }(\mathrm{km})\end{array}$ & $\begin{array}{c}\text { Length of actual } \\
\text { migratory path }(\mathrm{km})\end{array}$ & $\begin{array}{c}\text { Migratory } \\
\text { directness }\end{array}$ & $\begin{array}{c}\text { Travel rate } \\
\left(\mathrm{km} \mathrm{d}^{-1}\right)\end{array}$ & $\begin{array}{c}\text { Migration } \\
\mathrm{duration}(\mathrm{d})\end{array}$ \\
\hline $\begin{array}{c}\text { Northwestern } \\
(\mathrm{N}=14)\end{array}$ & 520.6 & 947.5 & 0.72 & 26.2 & 32.3 \\
Central western & $(78.89,27-1143)$ & $(252.01,27-3239)$ & $(0.06,0.35-1.0)$ & $(3.16,3.0-46.0)$ & $(5.36,9.2-70.4)$ \\
$(\mathrm{N}=12)$ & 393.9 & 504.8 & 0.84 & 30.1 & 17.6 \\
Central eastern & $(94.72,106-1084)$ & $(133.88,110-1310)$ & $(0.03,0.62-0.97)$ & $(3.04,12.7-48.7)$ & $(4.50,2.7-56.5)$ \\
$(\mathrm{N}=14)$ & 573.2 & 951.0 & 0.68 & 34.0 & 27.2 \\
1 -way ANOVA & $(69.51,41-1123)$ & $(162.28,60-2396)$ & $(0.05,0.28-0.99)$ & $(2.52,16.9-47.5)$ & $(3.98,3.3-61.9)$ \\
& $(\mathrm{df}=2, \mathrm{p}=0.30)$ & $(\mathrm{df}=2, \mathrm{p}=0.20)$ & $(\mathrm{df}=2, \mathrm{p}=0.09)$ & $(\mathrm{df}=2, \mathrm{p}=0.16)$ & $(\mathrm{df}=2, \mathrm{p}=0.10)$ \\
\hline
\end{tabular}

Table 2. Caretta caretta. Pearson product-moment correlation analyses relating the size of 40 loggerheads (as measured by straight carapace length from nuchal notch to posterior marginal tip) to the characteristics of their postnesting migrations. The loggerheads were from 3 rookeries in Florida (see Fig. 1). Migratory directness is the length of the shortest possible migratory path divided by the length of the actual migratory path. The correlation coefficient is given for variables that are significantly related $(\mathrm{p}<0.05)$

\begin{tabular}{|cccccc|}
\hline $\begin{array}{c}\text { Length of shortest possible } \\
\text { migratory path }(\mathrm{km})\end{array}$ & $\begin{array}{c}\text { Length of actual } \\
\text { migratory path }(\mathrm{km})\end{array}$ & $\begin{array}{c}\text { Migratory } \\
\text { directness }\end{array}$ & $\begin{array}{c}\text { Travel rate } \\
\left(\mathrm{km} \mathrm{d}^{-1}\right)\end{array}$ & $\begin{array}{c}\text { Migration } \\
\text { duration }(\mathrm{d})\end{array}$ \\
\hline Carapace length $(\mathrm{cm})$ & $\begin{array}{c}0.362 \\
(\mathrm{p}=0.022)\end{array}$ & $\begin{array}{c}0.338 \\
(\mathrm{p}=0.033)\end{array}$ & $\begin{array}{c}-0.376 \\
(\mathrm{p}=0.017)\end{array}$ & $\begin{array}{c}\mathrm{NS} \\
(\mathrm{p}=0.317)\end{array}$ \\
$(\mathrm{p}=0.344$ \\
\end{tabular}



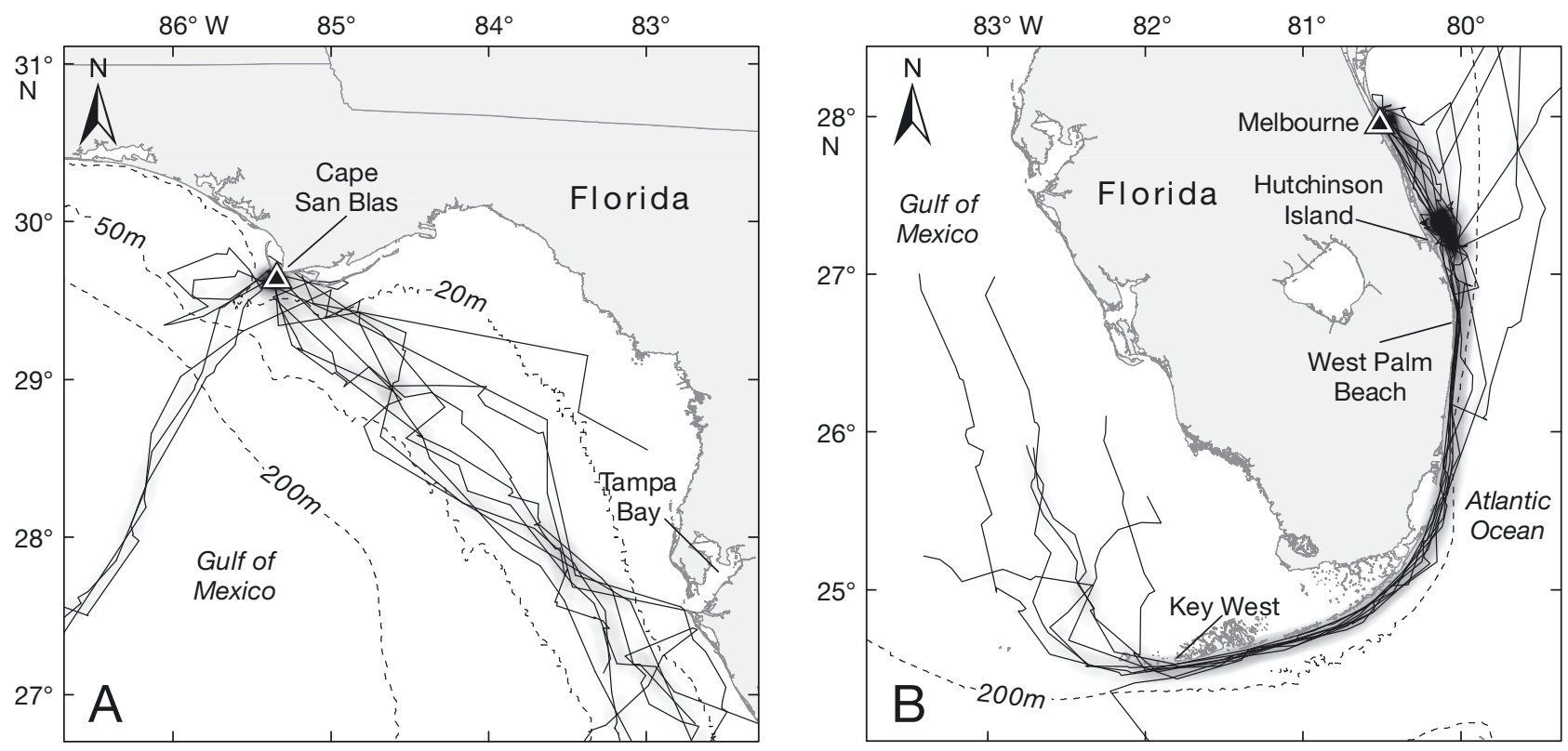

Fig. 3. Caretta caretta. (A) Postnesting migratory paths of 10 loggerheads from the northwestern rookery that were outfitted with a platform terminal transmitter (PTT) while nesting near Cape San Blas ( $\Delta$ ) during 1999 and 2000. Three paths coincided heading southwest towards the Yucatán Peninsula (Mexico) and 7 paths coincided heading southeast between the 20 and $50 \mathrm{~m}$ depth contours. (B) Postnesting migratory paths of 12 loggerheads from the central eastern rookery that were outfitted with a PTT while nesting near Melbourne ( $\Delta$ ) during 1998 to 2000. All paths coincided to some extent along the coast of southeast Florida. The shading indicates the relative concentration of migratory paths, expressed as the total length of migratory paths within a $10 \mathrm{~km}$ (radius) region

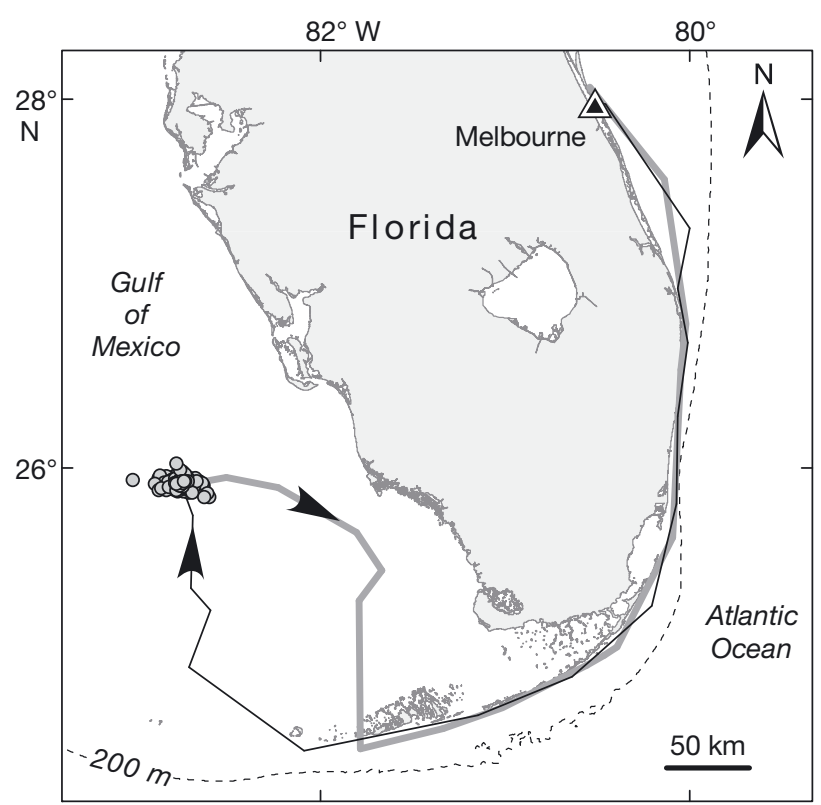

Fig. 4. Caretta caretta. The postnesting migration (thin black line, 13 August to 3 September 2000), residency at a foraging site (O, 3 September 2000 to 24 April 2002), and subsequent prenesting migration (thick grey line, 26 April to 14 May 2002) of a loggerhead from the central eastern rookery that was outfitted with a platform terminal transmitter while nesting near Melbourne ( $\Delta$ ) on 13 August 2000 migrations for 9 of these 10 turtles were restricted to the continental shelf of western Florida. During their postnesting migrations, these 9 turtles spent more time at or near the surface (within $3 \mathrm{~m}$ ) during the day than during the night, and more time at or near the bottom (within $5 \mathrm{~m}$ ) during the night than during the day (Table 4). Overall, these 9 loggerheads spent more time at or near the surface during their postnesting migrations than they did when in residence at foraging sites (Table 5).

The 10th turtle spent about 2 wk travelling through oceanic waters $(>200 \mathrm{~m})$, and during this period was at or near the surface $72.3 \%$ of the time, and between depths of 10 and $35 \mathrm{~m} 20.8 \%$ of the time. This turtle spent more than twice as much time at depths from 10 to $35 \mathrm{~m}$ during the night $(29.3 \%$ of the time from $20: 00$ to $08: 00 \mathrm{~h})$ than during the day $(12.8 \%$ of the time from 08:00 to 20:00 h).

\section{DISCUSSION}

As in the present study, the postnesting migrations of loggerheads in many parts of their range typically last about 30 d (Blumenthal et al. 2006, Luschi et al. 2006, Zbinden et al. 2008, Marcovaldi et al. 2010) 
Fig. 5. Caretta caretta. Postnesting migratory paths of 2 loggerheads from the central eastern rookery that crossed the Florida Current (shown by the largest arrows). The loggerheads were outfitted with a platform terminal transmitter (PTT) while nesting near Melbourne (MB, $\Delta$ ) during August 1999. The size and orientation of arrows indicate the velocity and direction of surface currents at PTT positions (O). The geostrophic current vectors and velocities were estimated using Marine Geospatial Ecology Tools for ArcGIS (Roberts et al. 2010) with sea surface height data derived from satellite altimetry

and usually involve net distances travelled from the nesting beach of a few hundred to a little more than $1000 \mathrm{~km}$ (Blumenthal et al. 2006, Hawkes et al. 2006, 2007, Luschi et al. 2006, Zbinden et al. 2008, Girard et al. 2009, Rees et al. 2010, Phillips 2011, Ceriani et al. 2012, Hart et al. 2012). The energetic cost of migrating for loggerheads depends upon various aspects of their behavior, including how they move both vertically and horizontally in the water column. Drag for swimming animals is greatest at the surface but quickly decreases below the surface and is minimized once the animal reaches a depth equivalent to about 2.5 to 3 times the thickness of its body (Hertel 1966). Using the formula of Epperly \& Teas (2002) to derive body depths for loggerheads in the present study ( 31.6 to $38.5 \mathrm{~cm}$ ), we determined that the turtles in our study could avoid the drag associated with the surface by swimming at a depth of 0.8 to $1.2 \mathrm{~m}$. There would be no further reduction in this drag by swimming at depths greater than $1.2 \mathrm{~m}$, but there would be additional energetic costs associated with increasing vertical movement in the water column. Nevertheless, there could be advantages to swimming farther below the surface than is necessary to avoid drag associated with the surface. The speed and direction of currents vary with depth, and loggerheads may find currents that are more favorable to swimming in a particular direction well below the surface of the
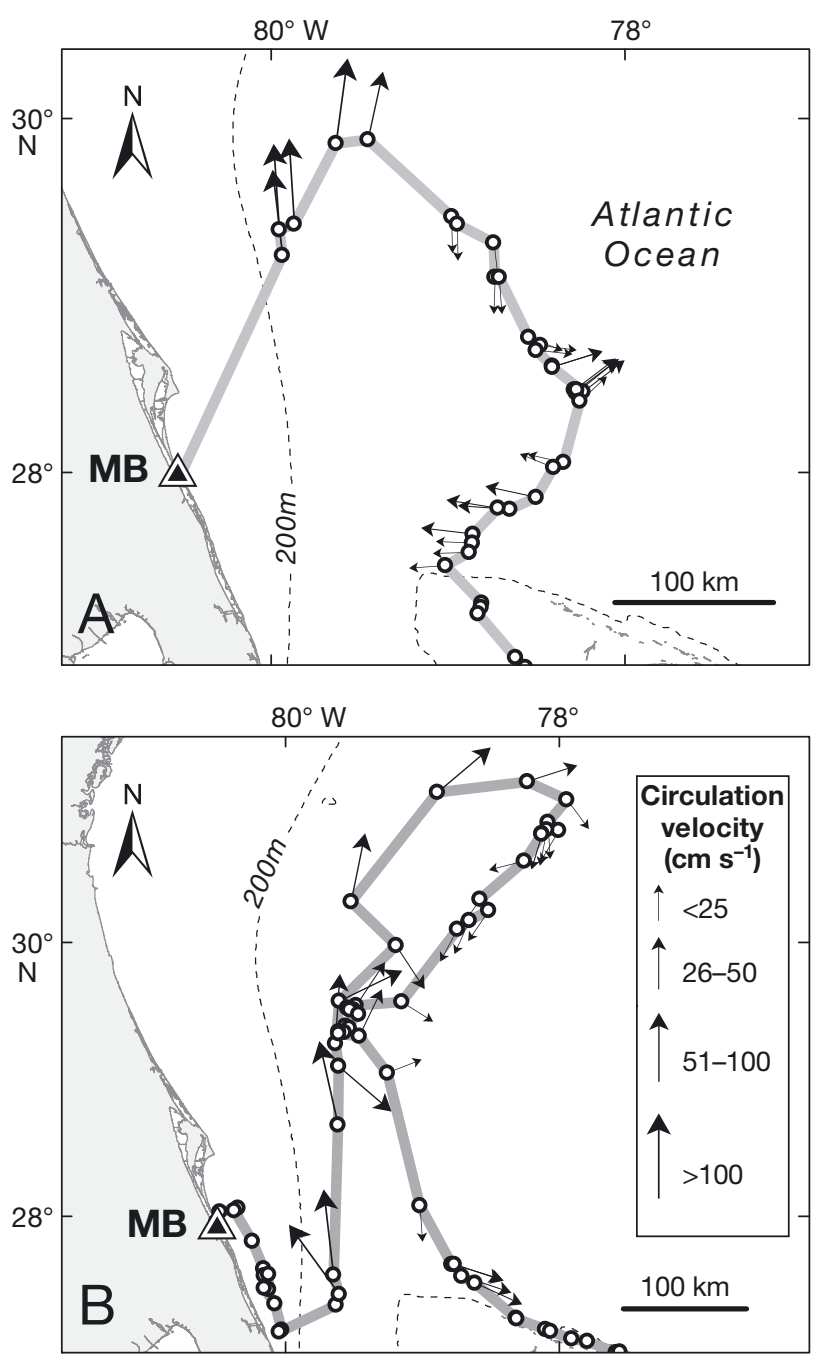

water. Loggerheads could also offset the energetic cost of deeper dives, and perhaps lower the overall cost of the migration, if they are able to forage during these dives. The energetic costs associated with the horizontal movements of a migrating loggerhead include similar considerations. A meandering path is likely to have a higher energetic cost than a

Table 3. Caretta caretta. Travel directions (mean $\pm \mathrm{SD}$ ) of the 5 loggerheads that crossed the northward flowing Florida Current. The travel directions are given for the time when the turtles were in the current and after they left the current. The loggerheads were outfitted with a platform terminal transmitter while nesting in the Archie Carr National Wildlife Refuge (near Melbourne central eastern rookery) during August 1998 (No. 1) and August 1999 (Nos. 2 to 5). The critical value for all the Watson's 2-sample tests for homogeneity was 0.19

\begin{tabular}{|c|c|c|c|c|c|}
\hline & No. 1 & No. 2 & $\begin{array}{c}\text { Loggerhead } \\
\text { No. } 3\end{array}$ & No. 4 & No. 5 \\
\hline Travel direction when in current & $36.0^{\circ}(0.39)$ & $74.8^{\circ}(0.67)$ & $53.9^{\circ}(0.77)$ & $21.4^{\circ}(0.75)$ & $37.6^{\circ}(0.57)$ \\
\hline Travel direction after leaving current & $132.4^{\circ}(0.87)$ & $159.1^{\circ}(1.17)$ & $148.0^{\circ}(0.77)$ & $175.0^{\circ}(1.12)$ & $184.1^{\circ}(0.96)$ \\
\hline Watson's 2-sample test of homogeneity & $0.45(\mathrm{p}<0.001)$ & $0.50(\mathrm{p}<0.001)$ & $0.41(\mathrm{p}<0.001)$ & $0.63(\mathrm{p}<0.001)$ & $0.35(\mathrm{p}<0.01)$ \\
\hline
\end{tabular}



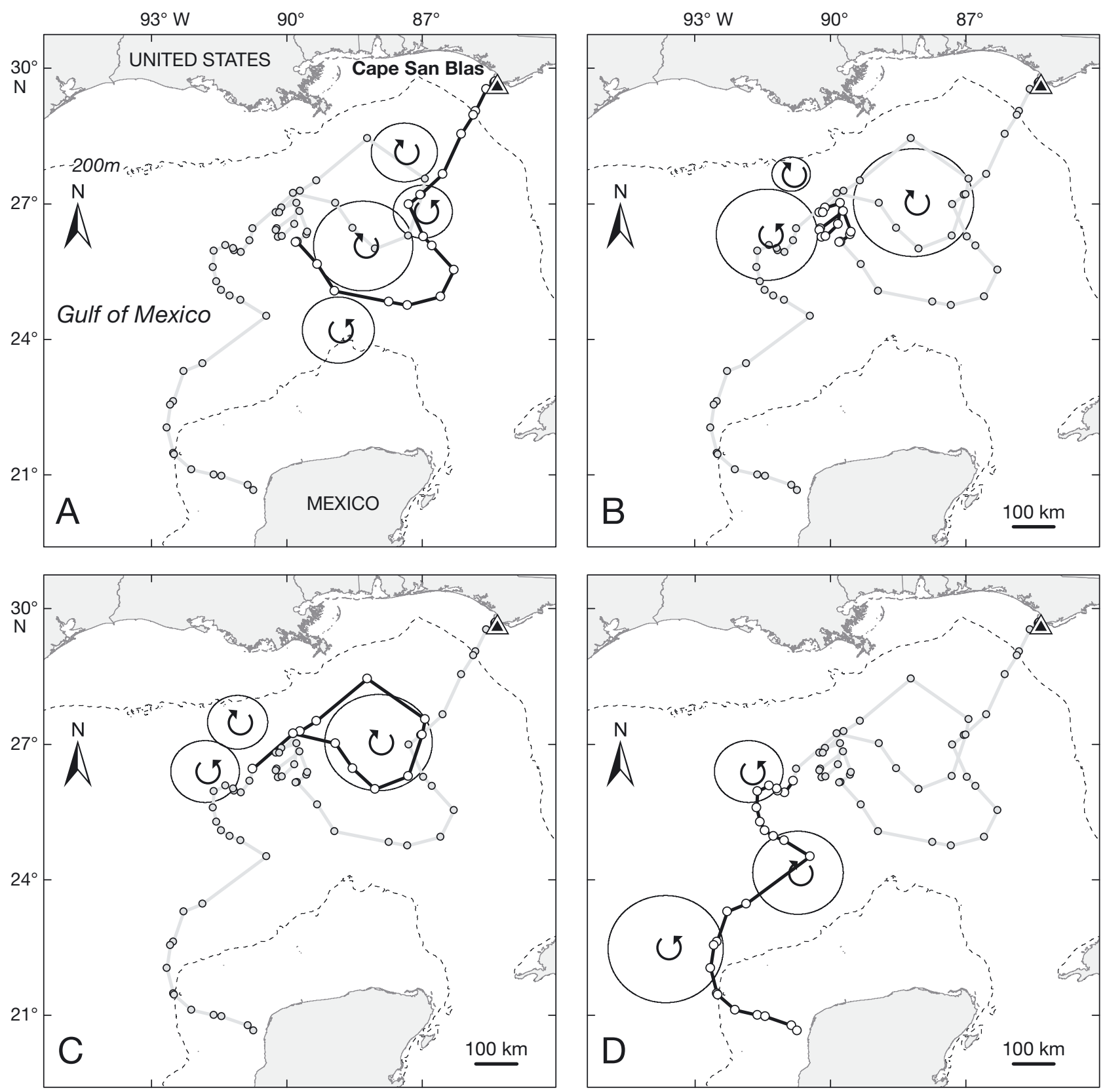

Fig. 6. Caretta caretta. The postnesting migration of a loggerhead from the northwestern rookery across the Gulf of Mexico, and the position and size of cyclonic and anticyclonic eddies (large circles) of the Loop Current at various periods during the migration. The loggerhead was outfitted with a platform terminal transmitter on 30 June 1999 while nesting on a beach near Cape San Blas $(\Delta)$. The black line represents the part of the migratory track temporally concurrent with the eddies shown. The travel path of the turtle was often at or near the edges of the eddies. The spatial extent and characteristics of the eddies were calculated using Marine Geospatial Ecology Tools for ArcGIS (Roberts et al. 2010) with data from Chelton et al. (2011) (cioss.coas. oregonstate.edu/eddies/). (A) 1 July to 6 August, (B) 7 to 19 August, (C) 20 August to 2 September, (D) 3 to 30 September

straight path unless the meandering path avoids unfavorable currents (or encounters favorable currents) or presents significant foraging opportunities.

The loggerhead with dive data that we tracked across oceanic waters spent most of the time near the surface $(<3 \mathrm{~m}$ deep $)$, indicating the possibility of swimming at the minimal depth necessary to avoid surface drag. Green turtles travelling through oceanic areas have also been found to spend most of the time near the surface, presumably benefitting from the same swimming strategy (Hays et al. 1999, Godley et al. 2002). Adult green turtles are not likely 
Table 4. Caretta caretta. Mean percentage of time (SEM, range) spent within $3 \mathrm{~m}$ of the surface and within $5 \mathrm{~m}$ of the bottom for 9 loggerheads by day and night during their postnesting migrations. Five turtles were from the northwestern rookery and 4 were from the central western rookery (see Fig. 1). All postnesting migrations were confined to the continental shelf of west Florida

\begin{tabular}{|c|c|c|}
\hline & $\begin{array}{c}\text { Within } 3 \mathrm{~m} \text { of } \\
\text { surface (\% of time) }\end{array}$ & $\begin{array}{l}\text { Within } 5 \mathrm{~m} \text { of the } \\
\text { bottom (\% of time) }\end{array}$ \\
\hline $\begin{array}{l}\text { Day } \\
(08: 00-20: 00 \mathrm{~h})\end{array}$ & $\begin{array}{l}\quad 25.6 \\
(4.9,7.6-46.4)\end{array}$ & $\begin{array}{c}52.8 \\
(7.2,24.5-82.6)\end{array}$ \\
\hline $\begin{array}{l}\text { Night } \\
(20: 00-08: 00 \mathrm{~h})\end{array}$ & $\begin{array}{c}18.5 \\
(3.5,6.5-35.6)\end{array}$ & $\begin{array}{c}63.4 \\
(5.0,34.2-79.0)\end{array}$ \\
\hline Paired $t$-test & $\begin{array}{c}t=2.70 \\
(\mathrm{df}=8, \mathrm{p}=0.03)\end{array}$ & $\begin{array}{c}t=2.50 \\
(\mathrm{df}=8, \mathrm{p}=0.04)\end{array}$ \\
\hline
\end{tabular}

Table 5. Caretta caretta. Mean percentage of time (SEM, range) spent within $3 \mathrm{~m}$ of the surface and within $5 \mathrm{~m}$ of the bottom for 9 loggerheads during their postnesting migrations and then during residency at foraging sites. Five turtles were from the northwestern rookery and 4 were from the central western rookery (see Fig. 1). All postnesting migrations and resident foraging areas were confined to the continental shelf of west Florida

\begin{tabular}{|ccc|}
\hline & $\begin{array}{c}\text { Within 3 m of } \\
\text { surface (\% of time) }\end{array}$ & $\begin{array}{c}\text { Within 5 m of the } \\
\text { bottom (\% of time) }\end{array}$ \\
\hline $\begin{array}{c}\text { Postnesting } \\
\text { migration }\end{array}$ & 24.1 & 60.4 \\
Residency at & $(4.0,7.1-42.1)$ & $(6.4,30.2-85.5)$ \\
foraging site & 10.7 & 84.5 \\
Paired $t$-test & $(1.2,4.7-14.7)$ & $(2.4,68.6-93.7)$ \\
& $t=3.03$ & $t=3.25$ \\
& $(\mathrm{df}=8, \mathrm{p}=0.02)$ & $(\mathrm{df}=8, \mathrm{p}=0.01)$ \\
\hline
\end{tabular}

to find foraging opportunities in oceanic waters and may be expected to move as efficiently as possible (swimming in a straight line just below the surface) through those areas. In contrast, adult loggerheads are able to forage pelagically in oceanic areas, and their travel paths are often characterized by large loops (Hatase et al. 2002, Hawkes et al. 2006, 2011, Rees et al. 2010). The postnesting migrations of all the loggerheads in the present study ended at neritic foraging grounds, but those that moved through oceanic areas could have foraged pelagically while travelling. Four of the loggerheads in our study moved across the oceanic center of the GOM (none had dive data). Two followed relatively straight paths (directness values $>0.85$ ), and appeared to be simply moving as efficiently as possible. The other 2 loggerheads made large-scale loops while migrating across the GOM; these loops often took the turtles along the edges of mesoscale eddies of the Loop Current, areas where relatively high productivity was likely (Biggs 1992, 1997). One of the loggerheads tracked during the postnesting migration in a previous study also looped in the oceanic area of the GOM around a mesoscale eddy (Girard et al. 2009). This looping travel behavior during the postnesting migrations could indicate pelagic foraging. However, further study is needed to better discern the behaviors of the loggerheads during this time.

The largest loggerheads in our study tended to migrate to foraging grounds that were farthest from the nesting beach, and these turtles usually had to either cross oceanic waters to reach these sites or could substantially shorten the travel distance to these sites by crossing oceanic waters. Consequently, the largest loggerheads nesting in Florida were those most likely to travel through oceanic areas and to possibly forage pelagically. This finding was similar to that in a study of loggerhead postnesting migrations in the Arabian Sea, where the largest turtles tended to spend the most time in oceanic areas (Rees et al. 2010). In contrast, studies of loggerhead postnesting migrations in some other ocean basins found that the smaller turtles were more likely to forage in oceanic areas (Hatase et al. 2002, Hawkes et al. 2006). The comparatively large loggerheads in our study that may have foraged pelagically did so over a relatively short time period, and otherwise had longterm foraging sites in neritic areas, where they were presumed to be primarily benthic foragers. The comparatively small postnesting loggerheads of some other studies that foraged in oceanic areas were likely to remain there for longer periods of time and may not have subsequently used neritic areas for foraging (Hatase et al. 2002, Hawkes et al. 2006). Additionally, the Florida loggerheads that may have foraged pelagically during their postnesting migrations could do the same when returning to the nesting beach. The possibility of short-term foraging in oceanic areas on the way to the nesting beach by loggerheads that might otherwise forage in neritic areas could complicate studies using isotopic signatures in tissue samples taken from nesting females to elucidate foraging strategies (see Reich et al. 2009).

For the migrating loggerhead in our study with dive data in an oceanic area, it is also interesting to note that when this turtle was not near the surface, it was usually found at depths from 10 to $35 \mathrm{~m}$, and that these deeper dives were more common at night. An almost identical behavior pattern was documented by Hays et al. (2001) for green turtles travelling through an oceanic area. The authors suggested that the deeper dives by the green turtles were made for 
resting, noting that these dives were most common at night, a natural period of inactivity for these diurnal animals. They also argued that these dives were unlikely to be below a depth where the turtles might have difficulty maintaining neutral buoyancy with fully inflated lungs (allowing them to remain passively motionless in the water column), but were deep enough to reduce silhouetting against the surface (decreasing vulnerability to visual predators such as sharks). The reasons for classifying these as resting dives for green turtles are equally applicable to explaining the same behavior in our loggerhead.

Migrants in neritic areas all spent less than half their time near the surface, and most spent only about 20 to $30 \%$ of their time there. However, the time they spent near the surface while migrating was still more than that spent near the surface when in residence at foraging sites, indicating that they might take some advantage of the efficiency of near-surface swimming while migrating. They also spent more time near the surface during the day, a time when these animals were likely to be more active. Nevertheless, all the loggerheads that migrated through neritic areas spent a majority of their time near the bottom both during the day and during the night. Bottom dives made during the night may have been mostly for resting. Those made during the day may have been to take advantage of currents more favorable for travel, but the prevalence of this behavior (in turtles moving in various directions) more likely indicates some benthic foraging. Additionally, migrating loggerheads that traveled through both neritic and oceanic areas had a slower rate of travel in neritic areas, perhaps due to benthic foraging. Migrating green turtles have also been found to exhibit similar differences in diving behavior and travel rates between oceanic and neritic areas, and were thought to likely forage as they travelled through neritic areas (Godley et al. 2002).

We documented behavior suggesting that some loggerheads with postnesting migrations through oceanic areas might initially forage for a relatively short period of time in neritic areas. Four of the loggerheads from the central eastern rookery spent from 4 to $17 \mathrm{~d}$ on the continental shelf offshore of Hutchinson Island (St. Lucie County and Martin County, about $80 \mathrm{~km}$ south of the nesting beach) early in their postnesting migrations. Three of these 4 turtles made the longest, second and fourth longest postnesting migrations of all turtles from this rookery, primarily traversing oceanic waters. Dodd \& Byles (2003) also found that 1 of the 4 postnesting loggerheads they tracked from the central eastern rookery spent about a month offshore of Hutchinson Island before continuing the postnesting migration. This turtle had the longest postnesting migration of the 4 turtles in their study, much of which occurred in oceanic waters.

Postnesting migratory paths with an oceanic component were less direct than those that were limited to the continental shelf. In the GOM, this was due in part to looping travel paths. In the Atlantic, the indirect nature of loggerhead travel paths in oceanic areas appeared to be largely due to the influence of the Florida Current. Studies of the orientation of both migrating loggerheads (Girard et al. 2009) and green turtles (Luschi et al. 1998, 2003) have shown that these turtles may not immediately compensate for the deflecting action of lateral currents, extending the length of travel paths to presumed targets.

The neritic foraging areas of some of the loggerheads that nest along the west coast of Florida are across the GOM. The loggerheads in the present study and in other studies (Girard et al. 2009, Hart et al. 2012) reached these areas by travelling across the oceanic waters of the GOM instead of by moving along the continental shelf that rings the GOM on the western side. The length of a travel path from nesting beaches on the Florida west coast (northeastern GOM) to the foraging grounds on the Campeche Bank, Mexico (southwestern GOM) via the continental shelf is about 3 times longer than a direct path across the GOM. However, because of the large amount of meandering (looping) sometimes observed in the present study, the length of the actual travel path for some turtles that crossed the GOM was about the same length as a straight path along the continental shelf of the GOM. This behavior contrasts in some respects with the behavior of loggerheads in the Caribbean and Mediterranean, where postnesting travel in oceanic waters is minimized by increasing the length of travel in neritic areas (Blumenthal et al. 2006, Broderick et al. 2007). The behavior we documented is somewhat more consistent with that described for loggerheads that nest on Masirah Island, Oman (Rees et al. 2010), and highlights the potential variability in the behavior of postnesting loggerheads. A possible advantage of travel in neritic areas is thought to be the availability of interim foraging possibilities (Godley et al. 2008), but for loggerheads such opportunities may also arise in oceanic areas.

The present study identified 4 migratory corridors used during the period of 1998 to 2000. Tracking studies of postnesting loggerheads both before and after the time period of our study suggest that the use of these corridors has remained constant at least 
over periods of decades. All the loggerheads in our study that nested near Cape San Blas (northwestern rookery) used either of 2 migratory corridors as they moved away from the nesting beach. In a study that tracked 4 postnesting loggerheads from this beach a decade later (2008 to 2010), these same 2 corridors were still used ( 2 turtles used 1 corridor and 2 turtles used the other corridor, Hart et al. 2012). The migratory corridor along the northern coast of Cuba was also used by other loggerheads from the central eastern rookery long before our study (Meylan et al. 1983, Dodd \& Byles 2003) and by loggerheads of the central western rookery about a decade after our study (Girard et al. 2009). The fourth migratory corridor documented in our study extended along the entire coast of southeast Florida, from Melbourne (Brevard County, where we outfitted nesting loggerheads with PTTs) to Key West (Monroe County). This corridor was narrowest (about $10 \mathrm{~km}$ wide) between West Palm Beach and Key West, where the travel paths of the turtles were constricted between the Florida coast and the western wall of the northward flowing Florida Current (opposite direction of postnesting migrations). There are southward-flowing nearshore countercurrents of the Florida Current (Yeung \& Lee 2002) that loggerheads might exploit during their postnesting migrations (as predicted by Caldwell et al. 1959). Ceriani et al. (2012) found that loggerheads from the central eastern rookery with foraging areas in the GOM were still using this corridor $10 \mathrm{yr}$ after our tracking periods. Postbreeding male loggerheads (Arendt et al. 2011) and adult male green turtles (B. Schroeder unpubl. data), and postnesting female green turtles (B. Schroeder unpubl. data) also migrate in this corridor.

Loggerheads have been known to retrace the path of the postnesting migration when moving from longterm foraging areas back to the nesting beach and then when returning again to foraging areas (Broderick et al. 2007, Marcovaldi et al. 2010). We tracked 1 loggerhead during 2 nesting seasons; this turtle used the migratory corridor along the southeast coast of Florida during the postnesting migration and then again during the return to the nesting beach $2 \mathrm{yr}$ later. All of the loggerheads with foraging areas in the GOM that nest along the east coast of Florida likely use this corridor for prenesting and postnesting migrations. Based on the annual number of loggerhead nests on the east coast of Florida from the central eastern rookery south to Miami (approximately Brevard County to Miami-Dade County) from 2006 to 2011 (mean of 52739 nests $\mathrm{yr}^{-1}$, Florida Fish and Wildlife Conservation Commission unpubl. data), we calculate that there were 9589 to 17560 female loggerheads nesting on those beaches each year (determined by using clutch frequencies of 3 to 5.5, National Marine Fisheries Service \& US Fish and Wildlife Service 2008). Assuming that between $14.3 \%$ (based on findings in Ceriani et al. 2012) and 53.3\% (based on findings in the present study) of these turtles had foraging areas in the GOM, the number of female loggerheads that used this corridor annually (during 2006 to 2011) when making reproductive migrations was between 1371 and 9370. The principal time period of these migrations is April to September.

Loggerheads using migratory corridors might be particularly vulnerable to mortality from humanrelated activities because turtles that are otherwise spread out over many, and often distant, foraging sites can become concentrated into relatively narrow (perhaps <10-km wide) corridors. Anthropogenic mortality factors that operate within these corridors during times of reproductive migrations can therefore affect a large number of adult turtles. There are a wide variety of commercial and recreational fisheries in US waters that are known to incidentally take loggerheads (Lewison et al. 2004, National Marine Fisheries Service \& US Fish and Wildlife Service 2008, Finkbeiner et al. 2011). Of particular concern are the shrimp bottom trawl fishery, pelagic and bottom longline fisheries, and demersal gillnet fisheries. Many of the flipper-tagged postnesting loggerheads in the study by Meylan et al. (1983) were later captured in shrimp trawls operating in southeast US waters.

Fisheries operating in the migratory corridor along the northern coast of Cuba have also been known to take postnesting loggerheads. In a flipper tag study, Meylan et al. (1983) found that 2 loggerheads were killed in fishing activities along the northern coast of Cuba shortly $(<2 \mathrm{mo})$ after nesting in Florida. In previous studies of postnesting movements of Florida loggerheads (Dodd \& Byles 2003, Girard et al. 2009), the tracking of 2 individuals ( 1 in each study) ended along the northern coast of Cuba; final locations were determined to be on land, suggesting that these turtles may have been directly or indirectly killed. The only 2 loggerheads in the present study that were not tracked through the entire postnesting migration were moving along the coast of northern Cuba when communications with their PTTs were lost. Prior to 2008, a legal fishery for sea turtles in Cuba existed; a complete ban on the harvest of all marine turtles was instituted in January 2008.

Loggerheads may be uniquely vulnerable to certain mortality factors because of where they travel 
and how they behave while migrating. Adult female loggerheads have not been known to travel in the oceanic zone of the GOM except during postnesting migrations (Girard et al. 2009, Hart et al. 2012, present study). Here, they could be at risk from activities such as pelagic longline fisheries, military exercises, and oil and gas exploration and production. Migrating loggerheads also spend more time near the surface than they do when resident at neritic foraging grounds. Turtles near the surface are at high risk of being struck by motorized vessels, and vessel strike injuries are commonly recorded in stranded (i.e. dead, sick, or injured) sea turtles. In Florida, vesselstrike injuries are more prevalent among adult-sized stranded loggerheads ( $>85 \mathrm{~cm}$ SCL) than among juvenile stranded loggerheads ( $<75 \mathrm{~cm}$ SCL) (A. Foley unpubl. data). The incidence of these injuries in adult loggerheads peaks temporally during the nesting season and spatially along the coast of southeast Florida (A. Foley unpubl. data), the area we describe here as 1 of 4 migratory corridors.

The recovery plan for the northwest Atlantic population of the loggerhead (National Marine Fisheries Service \& US Fish and Wildlife Service 2008) identified 5 recovery units. The loggerhead rookeries in the present study are a major part of 2 of these recovery units. The northwestern rookery represents most of the nesting in the Northern Gulf of Mexico Recovery Unit (NGMRU) (Turtle Expert Working Group 2009), and the central eastern and central western rookeries are the areas with the greatest numbers of loggerhead nests on each coast in the Peninsular Florida Recovery Unit (PFRU) (primarily Brevard County and Sarasota County, respectively, Meylan et al. 1995). The broad overlapping of postnesting migratory paths of loggerheads from each of these 2 recovery units in the GOM indicates that these turtles were likely exposed to many of the same potential threats in this area. However, only the adult female loggerheads from the PFRU would seem to face threats in the Atlantic. Postnesting loggerheads from the PFRU (both east and west coast) had postnesting migratory paths in the Atlantic, but none of the turtles from the NGMRU in our study or in another study (Hart et al. 2012) were found to migrate into the Atlantic. Loggerheads from both of these recovery units migrated through the waters of more than 1 country, underscoring the potential need for international coordination to address threats along some of their migratory routes.

Characterizing the behavior of loggerheads during reproductive migrations and identifying corridors or hot spots can help direct and prioritize conservation efforts that prevent or reduce the likelihood that anthropogenic mortality factors will intersect with concentrated aggregations of adult turtles. The identification and subsequent protection of loggerheads in all the areas in which they live or travel is critical to the recovery of the species.

Acknowledgements. This study was funded in part by the US Department of Commerce, National Oceanic and Atmospheric Administration, under PO\# 40-WC-NF-004557 to the Florida Fish and Wildlife Conservation Commission. The statements, findings, conclusions, and recommendations are those of the authors and do not necessarily reflect the views of the National Oceanic and Atmospheric Administration, US Fish and Wildlife Service, or any branch of the federal government. Funding was also provided by the US Fish and Wildlife Service and the Florida Sea Turtle License Plate. We are grateful for the assistance of D. Bagley, L. Ehrhart, and the University of Central Florida Marine Turtle Research Group; J. McCarthy and members of the Sarasota Turtle Watch; M. Lamont and other graduate students from the University of Florida working at Cape San Blas; and B. Witherington and S. Hirama. We also thank our friend and colleague, T. Redlow, who was an integral part of this project. R. Giove and B. Combs (Florida Fish and Wildlife Conservation Commission, Fish and Wildlife Research Institute) provided assistance with spatial analyses. D. Douglas (US Geological Survey, Alaska Service Center) shared customized Argos data filtering routines and provided advice on data handling and interpretation. E. Leone (Florida Fish and Wildlife Conservation Commission, Fish and Wildlife Research Institute) provided statistical advice. The manuscript was improved by the reviews of A. Meylan, B. Crowder, E. Leone, and 4 anonymous reviewers. The work was conducted under the authorization granted to the Florida Fish and Wildlife Conservation Commission in a Section 6 Endangered Species Act Cooperative Agreement with the US Fish and Wildlife Service.

\section{LITERATURE CITED}

Agostinelli C, Lund U (2011) R package 'circular': circular statistics (version 0.4-3). http://r-forge.r-project.org/ projects/circular/

Amante C, Eakins BW (2009) ETOPO1 1 arc-minute global relief model: procedures, data sources and analysis. NOAA Tech Memo NESDIS NGDC-24

Arendt MD, Segars AL, Byrd JI, Boynton J, Schwenter JA, Whitaker JD, Parker L (2011) Migration, distribution, and diving behavior of adult male loggerhead sea turtles (Caretta caretta) following dispersal from a major breeding aggregation in the western North Atlantic. Mar Biol 159:113-125

Balazs GH, Miya RK, Beavers SC (1996) Procedures to attach a satellite transmitter to the carapace of an adult green turtle, Chelonia mydas. In: Keinath JA, Barnard DE, Musick JA, Bell BA (comps) Proc 15th Annu Symp Sea Turtle Biology and Conservation. NOAA Tech Memo NMFS-SEFSC-387, p 21-26

Batschelet E (1981) Circular statistics in biology. Academic Press, New York, NY 
Biggs DC (1992) Nutrients, plankton, and productivity in a warm-core ring in the western Gulf of Mexico. J Geophys Res 97:2143-2154

Biggs DC, Zimmerman RA, Gasca R, Suarez-Morales E, Castellanos I (1997) Note on plankton and cold-core rings in the Gulf of Mexico. Fish Bull 95:369-375

Blumenthal JM, Solomon JL, Bell CD, Austin TJ and others (2006) Satellite tracking highlights the need for international cooperation in marine turtle management. Endang Species Res 2:51-61

Bolten AB (2003) Active swimmers, passive drifters: the oceanic juvenile stage of loggerheads in the Atlantic system. In: Bolton AB, Witherington BE (eds) Loggerhead sea turtles. Smithsonian Institution Press, Washington, DC, p 63-78

Bräutigam A, Eckert KL (2006) Turning the tide: exploitation, trade and management of marine turtles in the Lesser Antilles, Central America, Colombia and Venezuela. TRAFFIC International, Cambridge

> Broderick AC, Coyne MS, Fuller WJ, Glen F, Godley BJ (2007) Fidelity and over-wintering of sea turtles. Proc R Soc Lond B Biol Sci 274:1533-1538

Caldwell DK, Carr A, Ogren LH (1959) The Atlantic loggerhead sea turtle, Caretta caretta (L.), in America. I. Nesting and migration of the Atlantic loggerhead turtle. Bull Fla State Mus 4:295-308

Ceriani SA, Roth JD, Evans DR, Weishampel JF, Ehrhart LM (2012) Inferring foraging areas of nesting loggerhead turtles using satellite telemetry and stable isotopes. PLoS ONE 7:e45335

> Chelton DB, Schlax MG, Samelson RM (2011) Global observations of nonlinear mesoscale eddies. Prog Oceanogr 91:167-216

Coll M, Piroddi C, Albouy C, Ben Rais Lasram F and others (2012) The Mediterranean Sea under siege: spatial overlap between marine biodiversity, cumulative threats and marine reserves. Glob Ecol Biogeogr 21:465-480

Collecte Localisation Satellites (2008) Argos user's manual. Collecte Localisation Satellites, Toulouse

Coyne MS, Godley BJ (2005) Satellite Tracking and Analysis Tool (STAT): an integrated system for archiving, analyzing and mapping animal tracking data. Mar Ecol Prog Ser 301:1-7

Crouse DT, Crowder LB, Caswell H (1987) A stage-based population model for loggerhead sea turtles and implications for conservation. Ecology 68:1412-1423

Department of the Interior and Department of Commerce (2011) Endangered and threatened species; determination of nine distinct population segments of loggerhead sea turtles as endangered or threatened. Fed Regist 76 : 58868-58952

Dodd CK, Byles R (2003) Post-nesting movements and behavior of loggerhead sea turtles (Caretta caretta) departing from east-central Florida nesting beaches. Chelonian Conserv Biol 4:530-536

Douglas DC, Weinsierl R, Davidson SC, Kays R, Wikelski M, Bohrer G (2012) Moderating Argos location errors in animal tracking data. Methods Ecol Evol 3:999-1007

Ehrhart LM, Bagley DA, Redfoot WE (2003) Loggerhead turtles in the Atlantic Ocean: geographic distribution, abundance, and population status. In: Bolten AB, Witherington BE (eds) Loggerhead sea turtles. Smithsonian Institution Press, Washington, DC, p 157-174

Epperly SP, Teas WG (2002) Turtle excluder devices-Are the escape openings large enough? Fish Bull 100:466-474
Finkbeiner EM, Wallace BP, Moore JE, Lewison RL, Crowder LB, Read AJ (2011) Cumulative estimates of sea turtle bycatch and mortality in USA fisheries between 1990 and 2007. Biol Conserv 144:2719-2727

> Girard C, Tucker AD, Calmettes B (2009) Post-nesting migrations of loggerhead sea turtles in the Gulf of Mexico: dispersal in highly dynamic conditions. Mar Biol 156: 1827-1839

> Godley BJ, Richardson S, Broderick AC, Coyne MS, Glen F, Hays GC (2002) Long-term satellite telemetry of the movements and habitat utilisation by green turtles in the Mediterranean. Ecography 25:352-362

> Godley BJ, Blumenthal JM, Broderick AC, Coyne MS, Godfrey $\mathrm{MH}$, Hawkes LA, Witt MJ (2008) Satellite tracking of sea turtles: Where have we been and where do we go next? Endang Species Res 4:3-22

Hart KM, Lamont MM, Fujisaki I, Tucker AD, Carthy RR (2012) Common coastal foraging areas for loggerheads in the Gulf of Mexico: Opportunities for marine conservation. Biol Conserv 145:185-194

Hatase H, Takai N, Matsuzawa Y, Sakamoto W and others (2002) Size-related differences in feeding habitat use of adult female loggerhead turtles Caretta caretta around Japan determined by stable isotope analyses and satellite telemetry. Mar Ecol Prog Ser 233:273-281

- Hawkes LA, Broderick AC, Coyne MS, Godfrey MS and others (2006) Phenotypically linked dichotomy in sea turtle foraging requires multiple conservation approaches. Curr Biol 16:990-995

> Hawkes LA, Broderick AC, Coyne MS, Godfrey MH, Godley BJ (2007) Only some like it hot - quantifying the environmental niche of the loggerhead sea turtle. Divers Distrib 13:447-457

Hawkes LA, Witt MJ, Broderick AC, Coker JW and others (2011) Home on the range: spatial ecology of loggerhead turtles in Atlantic waters of the USA. Divers Distrib 17: $624-640$

> Hays GC, Luschi P, Papi F, del Seppia C, Marsh R (1999) Changes in behaviour during the inter-nesting period and post-nesting migration for Ascension Island green turtles. Mar Ecol Prog Ser 189:263-273

- Hays GC, Akesson S, Broderick AC, Glen F and others (2001) The diving behaviour of green turtles undertaking oceanic migration to and from Ascension Island: dive durations, dive profiles and depth distribution. J Exp Biol 204:4093-4098

Heppell SS (1998) Application of life-history theory and population model analysis to turtle conservation. Copeia $367-375$

Hertel H (1966) Structure, form, movement. Reinhold, New York, NY

Lewison RL, Freeman SA, Crowder LB (2004) Quantifying the effects of fisheries on threatened species: the impact of pelagic longlines on loggerhead and leatherback sea turtles. Ecol Lett 7:221-231

> Limpus CJ, Miller JD, Parmenter CJ, Reimer D, McLachlan N, Webb R (1992) Migration of green (Chelonia mydas) and loggerhead (Caretta caretta) turtles to and from eastern Australian rookeries. Wildl Res 19:347-358

> Luschi P, Hays GC, del Seppia C, Marsh R, Papi F (1998) The navigational feats of green sea turtles migrating from Ascension Island investigated by satellite telemetry. Proc R Soc Lond B Biol Sci 265:2279-2284

Luschi P, Hays GC, Papi F (2003) A review of long-distance movements by marine turtles, and the possible role of 
ocean currents. Oikos 103:293-302

Luschi P, Lutjeharm JRE, Lambardi R, Mencacci R, Hughes GR, Hays GC (2006) A review of migratory behaviour of sea turtles off southeastern Africa. S Afr J Sci 102:51-58

Mansfield KL, Saba VS, Keinath JA, Musick JA (2009) Satellite tracking reveals a dichotomy in migration strategies among juvenile loggerhead turtles in the northwest Atlantic. Mar Biol 156:2555-2570

Marcovaldi MÂ, Lopez GG, Soares LS, Lima EHSM, Thomé JCA, Almeida AP (2010) Satellite tracking of female loggerhead turtles highlights fidelity behavior in northeastern Brazil. Endang Species Res 12:263-272

McClellan CM, Read AJ (2007) Complexity and variation in loggerhead sea turtle life history. Biol Lett 3:592-594

> Meylan AB, Bjorndal KA, Turner BJ (1983) Sea turtles nesting at Melbourne Beach, Florida. II. Post-nesting movements of Caretta caretta. Biol Conserv 26:79-90

Meylan A, Schroeder B, Mosier A (1995) Sea turtle nesting activity in the State of Florida 1979-1992. Fla Mar Res Publ 52

Morreale SJ, Standora EA (2005) Western North Atlantic waters: crucial developmental habitat for Kemp's ridley and loggerhead sea turtles. Chelonian Conserv Biol 4: 872-882

National Marine Fisheries Service and US Fish and Wildlife Service (2008) Recovery plan for the northwest Atlantic population of the loggerhead sea turtle (Caretta caretta), Second Revision. National Marine Fisheries Service, Silver Spring, MD

NOAA National Geophysical Data Center (2009) US Coastal Relief Model. www.ngdc.noaa.gov/mgg/coastal/crm.html (accessed 13 December 2011)

Phillips K (2011) Beyond the beach: population trends and foraging site selection of a Florida loggerhead nesting assemblage. MSc thesis, University of Miami, FL

R Core Team (2012) R: A language and environment for statistical computing. R Foundation for Statistical Computing, Vienna. www.R-project.org/

Rees AF, Al Saady S, Broderick AC, Coyne MS, Papathanasopoulou N, Godley BJ (2010) Behavioural polymorphism in one of the world's largest populations of loggerhead sea turtles Caretta caretta. Mar Ecol Prog Ser 418:201-212

Reich KJ, Bjorndal KA, Frick MG, Witherington BE, Johnson C, Bolten AB (2009) Polymodal foraging in adult female loggerheads (Caretta caretta). Mar Biol 157:113-121

Roberts JJ, Best BD, Dunn DC, Treml EA, Halpin PN (2010)

Editorial responsibility: Brendan Godley,

University of Exeter, Cornwall Campus, UK
Marine Geospatial Ecology Tools: an integrated framework for ecological geoprocessing with ArcGIS, Python, R, MATLAB, and C++. Environ Model Softw 25: 1197-1207

> Salmon M, Wyneken J (1987) Orientation and swimming behavior of hatchling loggerhead turtles Caretta caretta L. during their offshore migration. J Exp Mar Biol Ecol 109:137-153

Schroeder BA, Foley AM, Bagley DA (2003) Nesting patterns, reproductive migrations, and adult foraging areas of loggerhead turtles. In: Bolten $A B$, Witherington $B E$ (eds) Loggerhead sea turtles. Smithsonian Institution Press, Washington, DC, p 114-124

Shamblin BM, Dodd MG, Bagley DA, Ehrhart LM and others (2011) Genetic structure of the southeastern United States loggerhead turtle nesting aggregation: evidence of additional structure within the peninsular Florida recovery unit. Mar Biol 158:571-587

Troëng S, Chacón D, Dick B (2004) Possible decline in leatherback turtle Dermochelys coriacea nesting along the coast of Caribbean Central America. Oryx 38: 395-403

Turtle Expert Working Group (2009) An assessment of the loggerhead turtle population in the western north Atlantic. NOAA Tech Memo NMFS-SEFSC-575

Witherington BE (1995) Observations of hatchling loggerhead turtles during the first few days of the lost year(s). In: Richardson JI, Richardson TH (comps) Proc 12th Annu Workshop Sea Turtle Biology and Conservation, NOAA Tech Memo NMFS-SEFSC-361, p 154-157

Witherington BE (2003) Biological conservation of loggerheads: challenges and opportunities. In: Bolten AB, Witherington BE (eds) Loggerhead sea turtles. Smithsonian Institution Press, Washington, DC, p 295-311

> Witt MJ, Akesson S, Broderick AC, Coyne MS and others (2010) Assessing accuracy and utility of satellite-tracking data using Argos-linked Fastloc-GPS. Anim Behav 80: $571-581$

Yeung C, Lee TN (2002) Larval transport and retention of the spiny lobster, Panulirus argus, in the coastal zone of the Florida Keys, USA. Fish Oceanogr 11:286-309

> Zbinden JA, Aebischer A, Margaritoulis D, Arlettaz R (2008) Important areas at sea for adult loggerhead sea turtles in the Mediterranean Sea: satellite tracking corroborates findings from potentially biased sources. Mar Biol 153: 899-906

Submitted: July 24, 2012; Accepted: April 17, 2013

Proofs received from author(s): July 9, 2013 